\title{
Z WYCIĄGÓW ARCHIWALNYCH WOJEWÓDZTWA LÓDZKIEGO: O METRYKACH PARAFIALNYCH DRUGIEJ POLOWY XIX I POCZĄTKU XX WIEKU
}

\section{WSTĘP}

Najstarsze polskie akty metrykalne pochodzą z XVI wieku. Na podstawie uchwał podjętych na Soborze Trydenckim (1545-1563) prowadzenie ksiąg metrykalnych stało się powszechnym obowiązkiem. Początkowo rejestrowano chrzty i śluby, a z czasem także zgony. Od XVII wieku do powinności proboszczów parafii rzymskokatolickich należało prowadzenie ksiąg metrykalnych osób ochrzczonych, bierzmowanych, zaślubionych i zmarłych oraz sporząazanie wykazów parafian. O ile w ówczesnych rejestrach ujawniano najczęściej tylko datę chrztu, o tyle od XVIII stulecia uzupełniano je już o datę urodzin (w przypadku aktu chrztu), a w księgach zgonów podawano albo datę śmierci, albo pogrzebu. $Z$ upływem czasu rozpowszechnił się zwyczaj wpisywania nazwy choroby będącej przyczyną śmierci, oraz wieku zmarłego.

$\mathrm{Na}$ staropolskie akty metrykalne składają się głównie dokumenty dotyczące rodzin szlacheckich i mieszczańskich. Gromadzenie danych osobowych przedstawicieli najniższych warstw społecznych należało jeszcze do rzadkości, jako że dziedziczenie nazwisk chłopskich z pokolenia na pokolenie upowszechniło się dopiero w XIX wieku, przy czym wpisy te ograniczały się co najwyżej do podania imion, ewentualnie wykonywanego zawodu.

Przełomowym etapem w historii kształtowania się dokumentacji metrykalnej jest okres zaborów. W okresie istnienia Księstwa Warszawskiego i Królestwa Polskiego kościelne księgi metrykalne stały się jednocześnie aktami stanu cywilnego i uzyskały status dokumentów o charakterze publiczno-prawnym, a sposób ich prowadzenia zaczął być regulowany przepisami wprowadzanymi przez poszczególnych zaborców. Każdą księgę sporządzano osobno dla każdego wyznania w dwóch egzemplarzach, z których jeden, tzw. unikat pozostawał na miejscu, a drugi (duplikat) był przekazywany do archiwum hipotecznego sądu powiatowego. Niezależnie od tego, proboszczowie kontynuowali prowadzenie kościelnych ksiąg w swoich parafiach. 
W okresie międzywojennym różnorodność przepisów dotyczących sposobu archiwizacji aktów stanu cywilnego była ujednolicana odpowiednimi rozporządzeniami i wyrokami Sądu Najwyższego. Ostatecznie po II wojnie światowej dekretem z 25 IX 1945 r. został wprowadzony jednolity w całym kraju system państwowej, powszechnej i świeckiej rejestracji cywilnej, co bezpośrednio wiązało się z powołaniem do życia nowych instytucji administracji państwowej, a mianowicie urzędów stanu cywilnego. Organy te do dziś tworzą tzw. księgi stanu cywilnego, składują je przez okres stu lat i docelowo przekazują do archiwów państwowych na wieczyste przechowanie. Parafie kościelne nadal prowadzą księgi metrykalne i nie mają obowiązku przekazywania ich do archiwów państwowych (https://archiwa.gov.p1/p1/dla-uzytkownikow/genealogia/typy-źródeł-wykorzystywanych-do-badań-genealogicznych, dostęp 15.04.2016).

\section{AKTY METRYKALNE}

Przedmiotem omówienia w niniejszym artykule są metryki parafialne, na które składają się akty urodzenia, ślubu i zgonu, pochodzące z Łodzi i innych powiatów województwa łódzkiego, $\mathrm{m}$. in.: bełchatowskiego, brzezińskiego, kutnowskiego, łaskiego, łęczyckiego, łowickiego, pabianickiego, piotrkowskiego, tomaszowskiego, zgierskiego.

Celem artykułu jest prezentacja wzorców gatunkowych wymienionych wyżej aktów metrykalnych w zestawieniu $\mathrm{z}$ ich realizacjami w języku polskim i rosyjskim, oraz uchwycenie różnic i podobieństw między nimi. Aktualny stan badań nad wspomnianymi dokumentami sprowadza się głównie do omówienia zagadnień historycznych i archiwistycznych podejmujących wątki dotyczące kształtowania się systemu rejestrowania aktów stanu cywilnego, sposobu przechowywania i katalogowania dokumentów, oceny stanu zachowania ksiąg, ich zawartości, czy też metod ich porządkowania i inwentaryzacji (por. np. Laszuk 1998, Pawiński 2002, Szkutnik 2012 i 2013, Związek 1993). Poza Niezbędnikiem genealoga (Hałuszczak 2012), w którym autor (poza omówieniem rysu historycznego i zawartości treściowej dokumentów) zestawił formularze łacińskich, niemieckich i rosyjskich dokumentów, opatrując je w thumaczenie na język polski oraz wyjaśniając podstawową terminologię i wybrane zagadnienia językowe, akty metrykalne nie doczekały się szczegółowego opracowania pod względem strukturalnym i lingwistycznym.

Zarchiwizowane dokumenty $\mathrm{w}$ bazie, do której dotarłam ${ }^{1}$ obejmują lata 1828-1912. Są to akty pochodzące $\mathrm{z}$ terenów znajdujących się pod zaborem ro-

${ }^{1}$ Materiały archiwalne dla potrzeb niniejszego artykułu zaczerpnęłam z Projektu indeksacji aktów stanu cywilnego i metryk kościelnych, zamieszczonego na stronie internetowej Polskiego Towarzystwa Genealogicznego (http://metryki.genealodzy.pl/metryki.php; http://metryki.genealodzy. $\mathrm{pl} /$ woj-LD, dostęp 16.02.2015). 
syjskim, sporządzone, w zależności od okresu, w którym powstawały, w języku polskim (od ok. 1810 r.) i rosyjskim (od 1868 r.). Język rosyjski został wprowadzony jako obowiązkowy przy sporządzaniu aktów Postanowieniem Komitetu Urządzającego z dnia 10 (22) listopada 1867 r. Artykuł pierwszy tego aktu brzmi następująco: „Z dniem 1 stycznia 1868 roku, księgi stanu cywilnego, dotyczące urodzeń śmierci i małżeństw dla osób wyznania rzymsko-katolickiego winny być prowadzone $\mathrm{w}$ języku rosyjskim i polskim a wypisy z nich czyli tak zwane akty stanu cywilnego, mają być wydawane w języku rosyjskim, a w razie potrzeby, we dwóch rosyjskim i polskim" (http://ebuw.uw.edu.pl/dlibra/docconten$\mathrm{t}$ ?id=168\&from=FBC, dostęp 10.03.2015).

Mimo takiego zarządzenia jeszcze na początku 1868 r. w wielu parafiach nadal pisano po polsku. Najprawdopodobniej takie nierosyjskojęzyczne akty z okresu, poczynając od przełomu roku 1868/69 do 1914/15, będąc rzecz jasna dokumentami, ówcześnie statusu dokumentu nie posiadały. Wśród przeanalizowanych przeze mnie materiałów najwcześniejsze metryki pisane w języku rosyjskim pochodzą z drugiej połowy stycznia 1868 roku, a dokładny termin wprowadzenia języka rosyjskiego w kancelariach parafialnych różnił się nieznacznie w poszczególnych województwach. Jeśli zaś chodzi o język, w jakim prowadzono skorowidze, to w niektórych kościołach były one jeszcze przez kilka lat prowadzone po polsku, a czasami tylko po rosyjsku, ale zawsze w obydwu tych przypadkach z zachowaniem porządku zgodnego z kolejnością liter w alfabecie polskim (http:// ebuw.uw.edu.pl/dlibra/doccontent?id=168\&from=FBC, dostęp 10.03.2015).

Na stronach Naczelnej Dyrekcji Archiwów Państwowych czytamy: „Zawartość ksiąg w XIX i XX w. zarówno katolickich, jak i ewangelickich była podobna. Akty metrykalne były krótkimi, zwięzłymi tekstami, zawierającymi niezbędne i najistotniejsze dla danego typu dokumentu informacje. W akcie chrztu zamieszczone są informacje dotyczące: daty urodzin (dzień, miesiąc, rok), przebiegu ceremonii (kiedy i gdzie się odbyła), ojca dziecka (imię i nazwisko, nazwisko rodowe matki ojca, zawód, stan), matki dziecka (imię i nazwisko, nazwisko rodowe, zawód, stan), rodziców chrzestnych (imiona i nazwiska, zawody), księdza udzielającego chrztu. Akt ślubu zawiera dane dotyczące: daty ślubu, przebiegu ceremonii (gdzie i kiedy się odbyła), księdza udzielającego ślubu, imion i nazwisk nowożeńców, ich statusu społecznego, stanu cywilnego, wieku, rodziców nowożeńców oraz świadków. W załącznikach do akt małżeństw mogą znajdować się odpisy metryk urodzenia przyszłych małżonków. Akt zgonu zawiera: datę i miejsce śmierci, wiek, imię i nazwisko zmarłego, przyczynę śmierci, stan cywilny zmarłego, dane o owdowiałym współmałżonku, dane o osieroconych dzieciach, dane dotyczące księdza odprawiającego pogrzeb oraz datę i miejsce pogrzebu" (http://www.archiwa.gov.pl/pl/dla-uytkownikow-archiwow/genealogia/116-typy-rode-wykorzystywanych-do-bada-genealogicznych.html, dostęp 20.02.2015).

Wszystkie trzy typy aktów, o których mowa w niniejszym artykule, powstawały według określonego wzorca. Obowiązujące szablony doczekały się opraco- 
wania w Podręczniku dla władz gminnych obejmujacym zbiór przepisów i postanowień, obowiazujących władze gminne w Królestwie Polskim, oprac. H. Konitza i F. Olszewskiego, Warszawa 1883 (http://ebuw.uw.edu.pl/dlibra/doccontent?id=168\&from=FBC, dostęp 20.03.2015).

Oto ich przykładowe wzorce:

Wzór aktu urodzenia

Działo się ... mca... 18... r. o godzinie ... . Stawił się osobiście N. N. (imię, nazwisko, zajęcie, miejsce zamieszkania i wiek) w obecności N. N. (imię i nazwisko, zatrudnienie i wiek), i N. N. (również) zamieszkałych w N. N. i okazał nam dziecko płci męskiej, oznajmując, iż urodziło się w N. N. (data i rok) o godz. ..., które spłodził z ślubną małżonką swoją N. N. z domu N. N. w wieku lat ... . Dziecku przy chrzcie świętym dokonanym w tymże dniu przez księdza N. N. nadano imiona N. N., rodzicami zaś chrzestnymi byli N. N. Akt ten odczytany oznajmiającemu i świadkom, a następnie podpisany przez nas i obecnych.

(Ksiądz N. N. ..., utrzymujący akty stanu cywilnego).

(podpisy ojca i świadków)

\section{Wzór aktu ślubnego}

Działo się ... . Oświadczamy, iż wobec świadków ... zawartym został religijny związek małżeński między ... a ... Z Związek ten poprzedziła jedna tylko zapowiedź, ogłoszona w tutejszym kościele parafialnym .... Od dwóch zapowiedzi nastąpiło zwolnienie z pozwolenia ....

Pozwolenie ojca narzeczonej udzielone zostało ustnie. Nowożeńcy oświadczają, iż zawarli między sobą umowę ślubną.

Obrzęd religijny małżeństwa został dokonany przez ... .

\section{Wzór aktu zejścia}

Działo się itd. Stawili się itd. i zeznali, iż dnia ... o godz. ... zmarł N. N., zamieszkały ..., urodzony w X. Z. syn itd., pozostawiwszy wdowę ... . Po naocznem przekonaniu się o śmierci X. Y. akt ten został odczytany obecnym, i przez nich podpisany.

Wzory aktów metrykalnych różniły się w zależności od okoliczności towarzyszących rejestrowanemu zdarzeniu. Istniały zatem następujące szablony dotyczące odpowiednio: urodzenia i połączonej z nim metryki o chrzcie świętym dziecka prawego, oddzielnie dla sytuacji, w której o urodzeniu oznajmiał ojciec lub inna osoba, w przypadku gdy ojciec nie był obecny przy sporządzeniu aktu; urodzenia dziecka nieprawego przez niezamężną kobietę, uznanego jednak przez ojca, a w przypadku gdy ojciec nie stawił się, dziecka nieprawego z niewiadomego ojca (w przypadku gdy matka osobiście nie oznajmia urodzenia dziecka, chcąc pozostać anonimową, dziecko uznaje się za narodzone z niewiadomych obojga rodziców); urodzenia dziecka znalezionego, bądź podrzuconego z ewentualnym wskazaniem osób je adoptujących. Odnośnie do wstępowania

\footnotetext{
${ }^{2}$ Do prezentacji materiału wybrałam szablony podstawowych i najbardziej rozpowszechnionych tekstów metryk.
} 
W związek małżeński oprócz podstawowego wzorca zatytułowanego ogólnie „wzór aktu ślubnego” istniały oddzielne szablony dla potwierdzenia ślubu, przy którym zaświadcza się uznanie dziecka poczętego przed zawarciem małżeństwa i potwierdzenia obrządku religijnego, który odbył się w innej parafii. Osobny formularz obowiązywał świadków zeznających w sytuacji, gdy jedna ze stron nie dostarczyła aktu urodzenia. Wzór aktu zgonu był jeden, zwany aktem zejścia, z odpowiednimi adnotacjami dotyczącymi przypadków śmierci w wyniku gwałtu, osób owdowiałych, rozwiedzionych, rodzicach i dzieciach pozostających po zmarłych.

We wspomnianym ,podręczniku” każdy ze wzorów aktów opatrzony jest szeregiem uwag dotyczących konieczności odpowiedniego sformułowania w dokumencie każdej odmiennej zaistniałej sytuacji, czy też odnotowania informacji innej niż ta zawarta w tekście-szablonie.

Oto przykłady omawianych dokumentów w języku polskim³:

\section{Akt urodzenia}

Działo się w Łodzi dnia szóstego stycznia tysiąc osiemset sześćdziesiątego ósmego roku o godzinie trzeciej społudnia. Stawił się Wilhelm Kowalski, rolnik w Dąbrowie zamieszkały, lat dwadzieścia sześć liczący wobec Józefa Pezolt piekarza tutejszego, lat trzydzieści jeden i Leonarda Agater, rolnik [a] ${ }^{4}$ w Dąbrowie zamieszkałego, lat dwadzieścia cztery liczącego i okazał Nam dziecię płci żeńskiej, urodzone w Dąbrowie dnia wczorajszego o godzinie dziesiątej rano z żony jego Agaty z N...ów [nazwisko rodowe nieczytelne] $]^{5}$ liczącej lat dwadzieścia jeden. Dziecięciu temu na chrzcie świętym dziś odbytym nadano imię Julianna, a rodzicami chrzestnymi byli wymienieni świadkowie i Julia Pezolt. Akt ten stawającemu i świadkom przeczytany, przez stawającego i świadka Agater podpisany nie został, gdyż oświadczyli, że pisać nie umieją.

\section{Akt ślubu}

Działo się we wsi Kurowicach dnia dziewiętnastego stycznia tysiąc osiemset sześdziesiątego ósmego roku o godzinie trzeciej po południu. Wiadomo czynimy, iż w przytomności świadków Marcina Wrzenia lat piędziesiąt sześć, Franciszka Piera lat trzydzieści mających, obydwu gospodarzy w wsi Dalkowie zamieszkałych - na dniu dzisiejszym zawarte zostało Religijne Małżeństwo pomiędzy Janem Brdoń - kawalerem lat dwadzieścia sześć mającym, urodzonym w wsi i tamże na służbie zostającym, synem Jana i Gertrudy z Kopów - małżonków Brdoniów w wsi Dalkowie zamieszkałych - a Agatą Padyk panną lat dwadzieścia pięć mającą - urodzoną w wsi Dalkowie i tamże na służbie zostającą córką niegdy Kacpra i żyjącej Magdaleny z Niewiadomych małżonków Padyków. Małżeństwo to poprzedziły trzy zapowiedzie w dniach Niedzielnych po sobie następujących - piątym, dwunastym i dziewiętnastym stycznia roku bieżącego w Kościele parafialnym Kurowickim ludowi na Nabożeństwo zgromadzonemu ogłoszone. Tamowanie małżeństwa nie zaszło. Nowi Małżonkowie oświadczają że żadnej umowy przedślubnej niezawarli.

${ }^{3}$ Wszystkie prezentowane w artykule teksty aktów przytaczam z zachowaniem pisowni zgodnej $\mathrm{z}$ oryginałem.

${ }^{4}$ Uzupełnienia w nawiasach kwadratowych pochodzą od Autorki artykułu.

${ }^{5} \mathrm{Z}$ uwagi na odręczne sporządzanie dokumentów wiele zapisów w księgach jest trudnych lub wręcz niemożliwych do odczytania. 
Obrzęd ten Religijny dopełniony został przez księdza Bonifacego Michałowicza administratora parafij Kurowice. Akt ten stawającym i świadkom pisać nieumiejącym przeczytany przez Nas tylko podpisany został

Ksiądz Bonifacy Michałowicz Administrator Parafij Kurowice utrzymujący Akta Stanu Cywilnego.

Akt zgonu

Działo się w wsi Parznie dnia pierwszego grudnia tysiąc osiemset sześćdziesiątego siódmego roku o godzinie dziewiątej rano, Stawili się Stanisław Barański lat siedemdziesiąt i Filip Musiałowski lat sześćdziesiąt siedem mających na Teofilowie zamieszkałych i oświadczyli że w dniu dwudziestym listopada roku bieżącego o godzinie dwunastej w południe umarła Agnieszka Gajda lat ośm mająca na Teofilowie urodzona córka Wawrzyńca i Maryanny małżonków Gajdów Komorników. Po przekonaniu się naocznie o zejściu Agnieszki Gajdy Akt ten stawającym przeczytany przez nas tylko podpisany gdyż oni pisać nie umieją. - Ksiądz Jan Konstanty Górecki Proboszcz parafii Parzna.

Dokumenty w języku rosyjskim pod względem formy i treści nie odbiegały od polskojęzycznych pierwowzorów, wręcz przeciwnie, wydają się być ich wiernymi kopiami. Jest to doskonale widoczne na przykładach zaprezentowanych poniżej aktów metrykalnych:

\section{Akt urodzenia}

Состоялось въ Лодзи втораго (четырнадцатаго) января тысяча девятьсотаго года, въ четыре часа дня. Явился Йоаннъ Рудольфъ Хафнеръ (Haffner) ${ }^{6}$ здешний работникъ двадцати семи льтъ отъ роду, въ присутствіи свидьтелей Августа Кригеръ, тридцати четырехъ льтъ и Лаврентия Рейнъ, тридцати однаго года отъ роду, здъшнихъ работниковъ и предъявиль намъ младенца женскаго пола родившагося въ Лодзи минувшаго декабря двадцать восьмаго (сего января девятаго дня) въ четыре часа дня отъ законной жены его Берты урожденной Гольцъ (Holz) двадцати однаго года отъ роду. Младенцу сему при совершенномъ сегодня святомъ крещеніи дано имя Ида (Ida) а восприемниками его были упомянутые свидътели и Паулина Шахтикейдеръ (Шиллеръ). Акт сей прочитанъ, по неграмотности отца и свидътелей, нами только подписанъ.

Akt ślubu

Состоялось въ Лодзи, января седьмаго (двадцатаго) дня тысяча восемьсотъ девяностаго седьмаго года въ пять часовъ вечера. Объявляемъ что въ присутствіи Адольфа Кихлеръ, брата жениха, тридцать двухъ льть и Эрнеста Шкидтке, двадцать девять льть, здђшнихъ жителей, заключенъ сегодня религиозный брачный союзъ между: Освальдомъ Иваномъ Кихлеръ (Küchler) холостым здъшнимъ бухгальтеромъ, двадцати льтъ и шести месяцевъ отъ роду, родившимся въ Лодзи, сыномъ покойнаго ткача Вильгельма Кихлеръ и жены его Матыльды урожденной Гермель Евангелическо-Аугсбурскаго исповедания, - и Адельмою Прейслеръ (Preisler) дЂвицею, двадцати льтъ и трехъ месяцевъ отъ роду, родившейся въ Лодзи дочерью ткача Эдуарда и Августы урожденной Фехнеръ, супруговъ Прейслеръ,

${ }^{6}$ Podawanie wariantów nazwisk zapisanych literami alfabetu łacińskiego było zjawiskiem bardzo częstym. Imiona w ten sposób zapisywano rzadziej. 
жительствующею въ Лодзи при родителяхъ Евангелическо-Аугсбурскаго исповедания. Браку сему предшествовали три оглашения въ здЂшней Евангелическо-Аугсбурской церкви сего января четвертаго (шестнадцатаго) дня въ воскресеніе и въ два предыдущія воскресенія. Новобрачные не заключили предбрачнаго договора. Актъ сей прочитанъ и подписанъ, только мать жениха неграмотна.

\section{Akt zgonu}

Состоялось въ Лодзи Января третьяго (шестнадцатаго) дня тысяча девятьсоть пятаго года, въ пять часовъ по полудни. Явились: Людовикъ Хикишъ, двадцати пяти льтъ и Луи Хеймейснеръ, тридцати восьми льтъ отъ роду, ткачи, жительствующіе въ Жубардзъ, и объявили намъ, что вчера въ двЊнадцать часовъ въ полдень умеръ въ Жубардзъ Іоаннъ Хикишъ (Hiekisch) двадцати одного дня отъ роду, родившійся въ Жубардзђ, сынъ упомянетаго Людовика Хикишъ и законной его жены Иды урожденной Шаде. По наочномъ удостовњреніи о кончинъ Іоанна Хикишъ, актъ сей прочитанъ, вторымъ объявляющимъ только и Нами подписанъ; первый объявляющій неграмотенъ.

\section{UWAGI KOŃCOWE}

Zarówno w polskojęzycznych, jak i rosyjskojęzycznych aktach do obowiązków sporządzającego dokument należało podanie w ustalonej kolejności: miejscowości rejestracji zdarzenia ${ }^{7}$, daty i godziny zgłoszenia, imienia, nazwiska oraz wieku stawającego, jego profesji, miejsca zamieszkania, danych świadków rejestracji, w przypadku aktu urodzenia - płci dziecka, miejscowości, daty i godziny jego narodzin, imienia i nazwiska (także rodowego) i wieku matki dziecka, wreszcie danych rodziców chrzestnych. W przypadku aktu ślubu lub zgonu dane osobowe dotyczą, rzecz jasna, uczestników obecnych podczas ceremonii adekwatnych do okoliczności.

Z powyższego wynika zatem, iż we wszystkich dokumentach każdego typu $\mathrm{z}$ łatwością można wyodrębnić ich stałe, następujące po sobie zawsze w tej samej kolejności części składowe oraz utarte formuły. Pierwszą część, otwierającą dokument stanowi formuła wstępna, rozpoczynającą się od słów Działo się.../ Состоялось..., wprowadzająca informacje o miejscu i czasie (data zawsze, bez wyjątku pisana była słownie, a w aktach rosyjskojęzycznych była podawana w dwóch wariantach, zgodnie z kalendarzem juliańskim, obowiązującym w Rosji do 1918 roku i gregoriańskim). Właściwa, druga część dokumentu zawierająca dane stawających, urodzonych i chrzczonych, czy też zmarłych, zaczynała się słowami Stawit (Stawili) się.../Явился (Явились)..., a w akcie ślubu Oświadczamy (Oznajmiamy, Wiadomo сzynimy).../Объявляем... Ostatnia część dokumentu, czyli jego formuła końcowa to tzw. uwierzytelnienie aktu. Rozpoczyna je formuła Akt ten stawajacym (i świadkom) przeczytany .../Aкm сей прочитан ..., uzupełnio-

${ }^{7}$ Jako że sporządzaniem dokumentów zajmowali się przeważnie księża, miejscem rejestracji jest najprawdopodobniej miejscowość, w której znajdowała się parafia. 
na dodatkowo o informację, która z osób obecnych przy sporządzeniu aktu była niepiśmienna. Pod treścią dokumentu następowały podpisy wszystkich umiejących pisać oraz zapisującego akt, z zaznaczeniem jego funkcji.

Ponadto cechą charakterystyczną omawianych dokumentów jest sam język, jakim były one pisane. W aktach $\mathrm{z}$ łatwością daje się wyodrębnić szereg form, noszących znamiona języka staropolskiego i starorosyjskiego. W rosyjskich tekstach uwagę zwraca obecność liter jer tylny „, (zawsze na końcu wyrazu, gdy ten kończy się na spółgłoskę twardą) oraz jat ', „”, a także występowanie swoistej końcówki-azo w dopełniaczu liczby pojedynczej przymiotników i liczebników rodzaju męskiego i nijakiego. Powszechnym było też użycie dawnej formy zaimka wskazującego $\mathrm{cb}$ 'ten'. W polskojęzycznych dokumentach odnotujmy chociażby zarejestrowane w tekstach zaprezentowanych w artykule formy ośm 'osiem' i społudnia 'po południu'.

Na zakończenie należy podkreślić, iż niniejszy artykuł prezentuje rezultaty jedynie początkowej fazy badań nad archiwalnymi aktami metrykalnymi i tym samym nie wyczerpuje potencjalnych możliwości wyciągnięcia pełnych wniosków, jakie daje nam przedstawiony tu szczątkowo materiał badawczy. Spostrzeżenia oraz zawarta w artykule analiza omawianych dokumentów służy jedynie jako przyczynek do rozwinięcia tematu, zgłębiania zainteresowań w tym kierunku, mogących zaowocować kolejnymi opracowaniami z tej dziedziny.

\section{Bibliografia}

Hałuszczak P. (2012), Niezbędnik genealoga, Mnichowo-Poznań.

Laszuk A. (1998), Ksiegi metrykalne i stanu cywilnego w archiwach państwowych w Polsce. Informator, Warszawa.

Pawiński M. (2002), Akta stanu cywilnego w Królestwie Polskim w pierwszej połowie XIX w., [w:] Archeion, t. 104, Warszawa, s. 203-206.

Szkutnik P. (2012), Regionalny poradnik genealogiczny - stan zachowania ksiag metrykalnych parafii rzymskokatolickich w gminie Uniejów, [w:] Biuletyn Uniejowski, t. 1, s. 177-188.

Szkutnik P. (2013), Sprowadzanie użytecznych cudzoziemców. Osadnicy w zachodniej części Królestwa Polskiego w pierwszej połowie XIX w. na przykładzie przodków autora, [w:] Kwartalnik Historii Kultury Materialnej, r. 61, nr 3, s. 409-422.

Związek J. (1993), Stan badań nad księgami metrykalnymi diecezji częstochowskiej, [w:] red. M. Cetwiński, Zeszyty historyczne Wyższej Szkoły Pedagogicznej w Częstochowie, t. 1, s. 51-68.

\section{Źródla internetowe}

http://www.archiwa.gov.pl/pl/dla-uytkownikow-archiwow/genealogia/116-typy-rode-wykorzystywanych-do-bada-genealogicznych.html

http://ebuw.uw.edu.pl/dlibra/doccontent?id=168\&from=FBC

http://metryki.genealodzy.pl/metryki.php

http://metryki.genealodzy.pl/woj-LD

www.piotrkow-tryb.ap.gov.pl 


\title{
Anna Iacovou
}

\section{FROM ARCHIVE EXTRACTS OF LODZ PROVINCE: ABOUT PARISH REGISTERS OF SECOND HALF OF 19 AND FIRST HALF OF 20 CENTURY}

(Summary)

The article is devoted to the description of old Polish public registers, dated in 19 and 20 century, containing three types of documents, such as birth (baptismal) certificates, marriage certificates and death certificates. The Author gives short commentary on the tradition of forming these kinds of documents in Poland from XVI century, which leads to the conclusion that during the time of Russian Partition, from the year 1868 they started to be written in Russian Language.

Examples of archive materials both in Polish and in Russian are enclosed and their unique construction, as well as main differences between them are paid attention to.

Keywords: the public register, parish register, certificate registry, birth certificate, marriage certificate, death certificate.

\section{Z WYCIĄGÓW ARCHIWALNYCH WOJ. LÓDZKIEGO: O METRYKACH PARAFIALNYCH 2 POL XIX I POCZ XX WIEKU}

\author{
(Streszczenie)
}

Artykuł jest poświęcony opisowi dokumentów zawartych w księgach metrykalnych pochodzących z przełomu XIX/XX wieku z terenów województwa łódzkiego. Do analizowanych tekstów należą akty urodzenia (chrztu), akty ślubu i akty zgonu. Autorka przedstawia krótką historię kształtowania się tych dokumentów w Polsce od XVI wieku, analizuje ich zawartość, specyficzną budowę, oraz zwraca uwagę na ważniejsze zjawiska językowe. Ponadto w artykule zamieszczono przykłady aktów metrykalnych zarówno w języku polskim, jak i w rosyjskim z uwagi na fakt, iż pod zaborem rosyjskim dokumenty te pisane były po rosyjsku od 1868 roku.

Słowa kluczowe: księgi metrykalne, metryki parafialne, akty metrykalne, akt urodzenia, akt ślubu, akt zgonu. 